\title{
Distribution of the endophytic fungi community in leaves of Bauhinia brevipes (Fabaceae)
}

Mariana Patrícia Amorim Hilarino ${ }^{1}$, Fernando Augusto de Oliveira e Silveira² ${ }^{2}$ Yumi Oki² Leonardo Rodrigues $^{1}$, Jean Carlos Santos ${ }^{3}$, Ary Corrêa Junior ${ }^{1}$, Geraldo Wilson Fernandes ${ }^{2,4}$ and Carlos Augusto Rosa ${ }^{1}$

Recebido em 7/01/2010. Aceito em 15/09/2011

\begin{abstract}
RESUMO
(Distribuição da comunidade de fungos endofíticos em folhas de Bauhinia brevipes (Fabaceae)). Fungos endofíticos representam um grande e ainda pouco explorado componente da biodiversidade. O trabalho avaliou a riqueza e a distribuição endofítica nas folhas de Bauhinia brevipes (Fabaceae). Foram obtidas 1110 colônias que foram agrupadas, por suas características morfológicas em 126 táxons. O número total de táxons por estágio foliar foi: 102 em folhas maduras, 93 em folhas recém-expandidas e 79 em não expandidas. O principal gênero de endofítico encontrado foi Phomopsis, seguido por Dothiorella, Pestalotiopsis e Acremonium. A riqueza e o número de isolados não foram estatisticamente influenciadas pela região foliar. Contudo, alguns táxons foram específicas de um estágio foliar; seis foram isoladas apenas em folhas não expandidas, nove em folhas recentemente expandidas e 17 foram encontradas apenas em folhas maduras. A composição endofítica variou de acordo com as regiões foliares; a similaridade (índice de Jaccard) entre as regiões das folhas de diferentes estágios variou de 0,36 a 0,46 , indicando uma alta variação espacial da comunidade de fungos endofíticos dentro da folha. A alta riqueza de endofíticos neste hospedeiro demonstra uma significante contribuição dos fungos para a biodiversidade tropical e a necessidade de pesquisas futuras nesta área.
\end{abstract}

Palavras-chave: interação planta-endofítico, Phomopsis, recorrência tecidual, riqueza de endófitos

\begin{abstract}
(Distribution of the endophytic fungi community in leaves of Bauhinia brevipes (Fabaceae)). Endophytic fungi represent large, yet unexplored components of biodiversity. This work evaluated the richness and the distribution of endophytes in the leaves of Bauhinia brevipes (Fabaceae). A total of 1110 colonies were recovered from the samples and grouped by their morphological traits into 126 taxa. The total number of taxa according to leaf development was: 102 in mature leaves, 93 in recently expanded leaves and 79 for unfolded leaves. The major endophyte genera were Phomopsis, followed by Dothiorella, Pestalotiopsis and Acremonium. The richness and the isolate numbers of endophytes were not statistically affected by leaf region. However, some taxa were leaf-age specific; six were isolated only from unfolded leaves, nine from recently expanded leaves and 17 were exclusively found in mature leaves. The composition of endophytes varied with leaf region; the similarities (Jaccard's Index) among the leaf regions of different leaf ages ranged from 0.36 to 0.46 , indicating a high spatial variation in the community of endophytic fungi inside the leaves. The high richness of endophytes in this host plant highlights a significant contribution of fungi to tropical biodiversity and the need for further research in this area.
\end{abstract}

Key words: plant-endophyte interaction, Phomopsis, tissue-recurrence, endophyte richness

\section{Introduction}

Microorganisms that asymptomatically inhabit internal plant tissues for at least one period of their life cycle are known as endophytes. Endophytic fungi have been found in every plant species examined to date (Arnold et al. 2000; Arnold et al. 2001; Tejesvi et al. 2007), have been found in all major plant lineages (Arnold et al. 2007), and colonize vegetative and reproductive parts of their hosts (Carroll 1988; Arnold et al. 2003). Endophytes can be transmitted not only vertically through seeds or other vegetative propagules, but also horizontally, via sexual and asexual spores (Wilson 1996), and the role of insects in endophyte dispersal has also been suggested (Devarajan \& Suryanarayan, 2006).

Endophytes are considered a ubiquitous and important component of fungal diversity, although understanding

\footnotetext{
1 Universidade Federal de Minas Gerais, Departamento de Microbiologia, Belo Horizonte, MG, Brazil

2 Universidade Federal de Minas Gerais, Departamento de Biologia Geral, Belo Horizonte, MG, Brazil

3 Universidade Federal de Uberlândia, Instituto de Biologia, Uberlândia, MG, Brazil

4 Author for correspondence: gwilson@icb.ufmg.br
} 
the scale of their diversity, host range, and geographic distributions remains unclear (Arnold et al. 2000). Given the high spatio-temporal variation in the composition and structure of endophytic fungi communities (Arnold et al. 2000; Gamboa \& Bayman 2001; Toofanee \& Dulymamode 2002; Arnold \& Herre 2003; Suryanarayanan \& Thennarasan 2004) tropical plants are argued to be hotspots of fungal diversity (Arnold \& Lutzoni 2007).

Investigations, such as from Arnold et al. (2000; 2001), have highlighted the high diversity of endophytes in moist tropical forests. In contrast, some studies report that dry tropical forests do not support a high diversity of endophytes. The low endophyte diversity in dry forests, in comparison to the high diversity in moist tropical forests, is a reflection of the influence of abiotic (annual rainfall, fire regime) and biotic (herbivore diversity, canopy openness) factors (Murali et al. 2007). Thus, further studies on the diversity of endophytes in tropical forests are needed to clearly estimate how this diversity varies in different tropical biomes. In addition, information on the effect of ontogenetic changes and distributions within plants could contribute to the understanding the role of fungal endophytes.

Understanding the distribution, richness and abundance of endophytes and host affinity over the geographic ranges of their hosts is the key to knowing the ecology and evolutionary context of endophyte-plant associations. Many researchers have highlighted the importance of the endophytes in plant resistance to climatic (Rodriguez et al. 2004) and soil conditions (Zaurov et al. 2001), pathogens (Mejía et al. 2008) and herbivores (Cheplick \& Faeth 2009), and such important roles can influence the diversity of an ecosystem as a whole.

Although the Brazilian Cerrado (savanna) represents one of the most important areas for biodiversity conservation (Myers et al. 2000), it remains one of the most unexplored biomes in terms of the fungal endophyte community. The aim of this study was to evaluate the richness and abundance of endophytic fungi found in the native shrub Bauhinia brevipes, a species we have been studying for the last 15 years (Cornelissen et al. 1997; Fernandes 1998; Cornelissen \& Fernandes 2001; Santos et al. 2008). We addressed the following questions. 1) Does endophyte abundance and richness increase with leaf age? Studies have demonstrated that leaf age influences the density of endophyte infection in leaves of tropical forest trees (Arnold \& Herre 2003). Therefore, variation in leaf traits during leaf maturation should affect plant colonization by endophytes (Duong et al. 2006). 2) Does endophyte abundance and richness vary among leaf regions of the host plant? The distribution of endophytic fungi in leaves is typically not homogenous (Cannon \& Simmons 2002) and if the community of endophytic fungi is spatially structured (Gamboa \& Bayman 2001; Arnold \& Herre 2003), it should be expected that different leaf parts support different communities and/or richness and abundance. The greater colonization of certain leaf parts may be related to more complex anatomical structure and/or susceptibility to infection (Cannon \& Simmons 2002).

\section{Material and methods}

This study was performed at the Estação Ecológica de Pirapitinga (EEP), in southeastern Brazil. The EEP is a human-made island formed during the construction of a water reservoir for a hydro-electrical power plant in 1965. The reservoir is located near of the city of Três Marias $\left(18^{\circ} 23^{\prime} \mathrm{S}\right.$, $45^{\circ} 20^{\prime} \mathrm{W}$ ), at an elevation of $560 \mathrm{~m}$ above sea level. The average annual temperature of the study site varies from 21 to $25^{\circ} \mathrm{C}$ and the mean annual precipitation is $1200 \mathrm{~mm}$. The EEP has an area of 1,100 ha and its vegetation is primarily Cerrado (Gonçalves-Alvim \& Fernandes 2001).

Bauhinia brevipes Vog. (Fabaceae) is a deciduous shrub up to 3m tall (Cornelissen et al. 1997) that loses its leaves at the onset of the dry season. At the end of the dry season (September) all individuals are leafless. Leaf growth starts synchronously at the onset of the rainy season (October), and leaf maturation may be observed until mid-rainy season (Cornelissen et al. 1997). Bauhinia brevipes is attacked by several free-feeding and galling insects (Cornelissen \& Fernandes 2001; Santos et al. 2008).

In order to evaluate the composition of endophyte communities, 15 individuals of $B$. brevipes were randomly selected and sampled in January 2004. Sampled plants were located at least $20 \mathrm{~m}$ from each other in order to avoid identical genets, as growth of ramets belonging to the same genet has been observed (G. W. Fernandes, unpublished data). From each plant, we randomly sampled six leaves belonging to three age classes from around the shrub canopy, two unfolded leaves, two recently expanded leaves, and two mature leaves, for a total of 90 leaves.

Leaves were immediately taken to the laboratory, kept at $4^{\circ} \mathrm{C}$ and stored for no longer than $24 \mathrm{~h}$ before the analyses. The leaf surface was sterilized by immersion in $70 \%$ ethanol for $1 \mathrm{~min}$, 3\% sodium hypochlorite for $3 \mathrm{~min}$ and $70 \%$ ethanol for $30 \mathrm{~s}$. Leaves were then rinsed in sterile distilled water for $30 \mathrm{~s}$ (Cannon \& Simmons 2002). Nine leaf fragments $(5 \times 3 \mathrm{~mm})$ were excised from each leaf, three from the leaf blade, three from the petiole, and three from the midvein $(n=810)$, for endophyte assessment. The fragments of each leaf region were placed onto PDA (Potato-Dextrose-Agar supplemented with cloramphenicol $100 \mathrm{mg} \cdot \mathrm{L}^{-1}$ to inhibit the growth of bacteria) Petri plates and incubated at $25^{\circ} \mathrm{C}$ for 5-15 days. After hyphae proliferation (from seven to 15 days) colonies were submitted to microculture on glass slides for examination of reproductive structures (Riddell 1950). For sporulating fungi, we used morphology-based taxonomy (Barnett \& Hunter 1972). The sterile isolates were separated according to similarity of morphological traits, including aerial mycelium form, colony and medium color, colony surface texture and margin characters. 
For molecular identification, the sterile isolates were grown on PDA Petri plates and incubated at $20^{\circ} \mathrm{C}$ for 10 days. The DNA extraction was performed according to De Hoog et al. (2005). The primers ITS 1 and ITS 4 were used to amplify the ITS 1 and ITS 2 sequences surrounding the $5.8 \mathrm{~S}$ - coding sequence of the ribosomal operon. These primers amplify a wide range of fungal targets and work well to analyze DNA isolated from individual organisms (White et al. 1990). PCR was run using a Gene Amp PCR System 2400 thermocycler $\left(5 \mathrm{~min}\right.$ at $94^{\circ} \mathrm{C} ; 30$ cycles of $30 \mathrm{~s}$ at $94^{\circ} \mathrm{C}, 30$ $s$ at $55^{\circ} \mathrm{C}$ and $30 \mathrm{~s}$ at $72^{\circ} \mathrm{C}$, followed by a final $7 \mathrm{~min}$ at $72^{\circ}$ C). Amplicons were analyzed in a $1 \%$ agarose gel stained with ethidium bromide.

The sequencing reaction was carried out by using ET Dye Terminator Kit for MegaBACE (GE Healthcare) combined with the automatic sequencing system Mega$\mathrm{BACE}^{\mathrm{TM}} 1000$, at the Laboratório de Biodiversidade e Evolução Molecular (Instituto de Ciências BiológicasUFMG). The nucleotide sequencing was analyzed comparatively with the NCBI GenBank database from the BLASTn (http://www.ncbi.nlm.nih.gov/blast). Molecular identification was considered from the sequences that showed the highest similarity (>97\%) with GenBank. The nucleotide sequence data were submitted and registered in GenBank. Some taxa, however, were not possible to determine to species due to the lack of taxonomic and genomic database information. Specimens were deposited in the Collection of Cells and Cultures at UFMG (CCC- UFMG).

The relative abundance curves were compared to a theoretical model of taxa abundance, lognormal distribution, through the Kolmogorov-Smirnov test for goodness of fit (Gamboa \& Bayman 2001). Moreover, taxon accumulation curves and bootstrap estimates of total taxa richness were inferred with EstimateS 8.0 (Colwell 2006).

In order to evaluate variation of endophyte abundance and richness among leaf regions within each leaf age, the data were analyzed by the non-parametric test of KruskalWallis with the average ordination (rank mean) compared by Tukey's test ( $\alpha=0.05)$ (Conover 1980; Zar 1996). The statistical program used was SigmaStat version 3.5 (Copyright $^{\oplus} 2006$ Systat Software, Inc.). The same procedures were used to evaluate variation in abundance and richness among leaf age. In order to compare the community of endophytes in $B$. brevipes, the similarity between leaf age and leaf regions was evaluated using Jaccard's index - JI (Magurran 1998):

$$
\mathrm{JI}=\mathrm{a} /(\mathrm{a}+\mathrm{b}+\mathrm{c})
$$

where "a" represents the number of taxa occurring in both samples, "b" represents the number of taxa restricted to sample 1 and "c" represents the number of taxa exclusive to sample 2. JI ranges from 0.0 (no taxa shared) to 1.0 (all taxa shared). A similarity matrix was built using the JI, which was then clustered using UPGMA as the clustering algorithm.

\section{Results}

A total of 1110 axenic cultures were obtained from 810 leaf fragments (an average of 74.3 colonies per plant). Fungi abundance conformed to a log-normal distribution (Kolmogorov-Smirnov test $\mathrm{D}=0.1163, p<0.01$ ). The taxon accumulation curve for individual plants did not reach an asymptote, suggesting the taxa richness of endophytic fungi was underestimated (Fig. 1).

Endophytic fungi colonized $81.7 \%$ of the leaf fragments of $88(97.8 \%)$ leaves from the sampled plants $(77.8 \%$ in unfolded, $86.3 \%$ in recently expanded and $81.1 \%$ in leaves). From the 1110 isolates recovered, 653 isolates $(58.83 \%)$ remained as mycelia sterilia in culture. The other 457 isolates did sporulate in culture and were identified into 18 taxa, whereas non-sporulating endophytes were grouped into 108 colonial taxa. Thirty-one taxa were commonly found in the leaves, comprising $60 \%$ of total colonies. Ninety-five taxa were rarely encountered (with less than 10 colonies). The most common genus was Phomopsis with 378 colonies (around $35 \%$ of total colonies) and 12 taxa. The genus Dothiorella (36 colonies, about $3.2 \%$ of total colonies) was the second most abundant, followed by Pestalotiopsis (25 colonies, $2.3 \%$ of the total colonies), taxon 91 (24 colonies, $2.16 \%$ of the total colonies), taxon 96 (22 colonies, $1.98 \%$ of the total colonies), and Acremonium (20 colonies, $1.8 \%$ of the total colonies). Furthermore, Phomopsis sp. 1, was the dominant taxon, with 99 colonies (8.9\% of total colonies) isolated from 13 out of the 15 sampled individual plants (Table 1).

The composition of endophytic fungi differed among leaf ages. Some taxa were age-specific for unfolded (six taxa), recently expanded (nine taxa) and mature leaves (17 taxa). Only 13 taxa of endophytic fungi were observed in all the three stages: Phomopsis (10 taxa), Dothiorella sp., Pestalotiopsis sp. 1 and Pestalotiopsis sp. 2.

Most of the endophytes were found in more than two leaf regions. The 31 most abundant endophyte taxa were

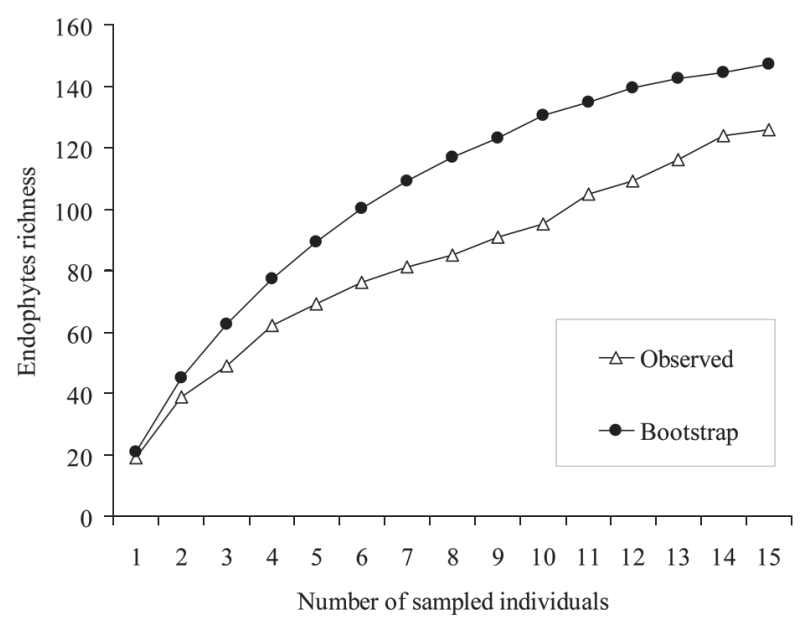

Figure 1. Taxon accumulation curves showing the number of Bauhinia brevipes individuals and the richness of endophytic fungi. 
Table 1. Isolate number of the 33 more abundant endophyte taxa (ranked according to abundance) found in different regions (petiole, mid-vein and leaf blade) of the leaves (unfolded, recently expanded and mature) from Bauhinia brevipes from Estação Ecológica de Pirapitinga, Três Marias, Minas Gerais, Brazil. The accession numbers for GenBank (http://www.ncbi.nlm.nih.gov/sites/entrez?db=nucleotide) are in the parentheses.

\begin{tabular}{|c|c|c|c|c|c|c|c|c|c|c|}
\hline \multirow{2}{*}{$\begin{array}{l}\text { Taxon } \\
\text { (Accession number) }\end{array}$} & \multicolumn{3}{|c|}{ Unfolded leaves } & \multicolumn{3}{|c|}{ Recently-expanded leaves } & \multicolumn{3}{|c|}{ Mature leaves } & \multirow[t]{2}{*}{ Tota } \\
\hline & Petiole & Mid-vein & Leaf blade & Petiole & Mid-vein & Leaf blade & Petiole & Mid-vein & Leaf blade & \\
\hline Phomopsis sp1 & 7 & 10 & 12 & 10 & 21 & 10 & 10 & 15 & 4 & 99 \\
\hline Phomopsis sp2 (JF723494) & 3 & 1 & 1 & 4 & 4 & 4 & 4 & 2 & 15 & 38 \\
\hline Phomopsis sp3 & 1 & 3 & 6 & 4 & 1 & 3 & 6 & 9 & 3 & 36 \\
\hline Phomopsis sp4 & 1 & 4 & 8 & 2 & 1 & 12 & 0 & 5 & 3 & 36 \\
\hline Dothiorella sp (JF723497) & 4 & 5 & 5 & 5 & 3 & 3 & 4 & 4 & 3 & 36 \\
\hline Phomopsis sp5 & 3 & 9 & 4 & 5 & 8 & 4 & 1 & 0 & 0 & 34 \\
\hline Phomopsis sp6 & 4 & 4 & 1 & 5 & 5 & 1 & 1 & 3 & 9 & 33 \\
\hline Phomopsis sp7(JF723496) & 4 & 4 & 8 & 2 & 3 & 5 & 2 & 0 & 0 & 28 \\
\hline Taxon 91 & 1 & 0 & 2 & 7 & 6 & 6 & 1 & 0 & 1 & 24 \\
\hline Phomopsis sp8 (JF723495) & 3 & 3 & 1 & 4 & 2 & 2 & 3 & 3 & 1 & 22 \\
\hline Taxon 96 & 0 & 1 & 0 & 0 & 3 & 0 & 2 & 12 & 4 & 22 \\
\hline Acremonium sp & 0 & 0 & 0 & 7 & 6 & 6 & 0 & 1 & 0 & 20 \\
\hline Taxon 57 & 4 & 5 & 0 & 9 & 0 & 1 & 0 & 0 & 0 & 19 \\
\hline Phomopsis sp11(JF723498) & 0 & 0 & 1 & 0 & 1 & 2 & 5 & 4 & 6 & 19 \\
\hline Taxon 61 & 1 & 2 & 2 & 1 & 1 & 0 & 2 & 4 & 5 & 18 \\
\hline Taxon 116 & 0 & 1 & 2 & 2 & 2 & 0 & 3 & 2 & 3 & 15 \\
\hline Pestalotopsis sp1 & 2 & 0 & 0 & 1 & 1 & 2 & 4 & 1 & 3 & 14 \\
\hline Phomopsis sp 9 & 0 & 1 & 1 & 0 & 0 & 2 & 2 & 6 & 1 & 13 \\
\hline Phomopsis sp10 & 1 & 1 & 5 & 0 & 1 & 0 & 1 & 0 & 3 & 12 \\
\hline Taxon 33 & 0 & 0 & 0 & 2 & 0 & 1 & 3 & 2 & 4 & 12 \\
\hline Taxon 54 & 0 & 0 & 0 & 0 & 0 & 0 & 2 & 9 & 1 & 12 \\
\hline Taxon 119 & 0 & 2 & 2 & 3 & 3 & 1 & 1 & 0 & 0 & 12 \\
\hline Taxon 5 & 1 & 0 & 0 & 0 & 1 & 1 & 2 & 2 & 4 & 11 \\
\hline Taxon 34 & 2 & 0 & 0 & 2 & 4 & 3 & 0 & 0 & 0 & 11 \\
\hline Taxon 65 & 1 & 0 & 0 & 2 & 0 & 1 & 2 & 3 & 2 & 11 \\
\hline Phomopsis sp12 (JF723493) & 0 & 0 & 0 & 3 & 0 & 0 & 3 & 5 & 0 & 11 \\
\hline Phoma sp (JF723492) & 2 & 2 & 0 & 3 & 1 & 0 & 2 & 0 & 0 & 10 \\
\hline Taxon 30 & 0 & 0 & 0 & 0 & 0 & 0 & 3 & 1 & 2 & 10 \\
\hline Taxon 26 & 0 & 0 & 0 & 3 & 0 & 0 & 3 & 2 & 2 & 10 \\
\hline Taxon 35 & 0 & 0 & 3 & 0 & 6 & 1 & 0 & 0 & 0 & 10 \\
\hline Taxon 50 & 0 & 0 & 0 & 1 & 1 & 1 & 4 & 2 & 1 & 10 \\
\hline Taxon 86 & 2 & 1 & 2 & 1 & 0 & 3 & 1 & 0 & 0 & 10 \\
\hline Pestalotopsis sp2 & 2 & 0 & 0 & 2 & 1 & 2 & 2 & 0 & 0 & 9 \\
\hline
\end{tabular}

found in all leaf regions. Similarities among the communities of endophytic fungi colonizing $B$. brevipes leaves were near 0.50 . The dendrogram produced three well-resolved groups, mature, unfolded and recently-expanded leaves based on leaf age (Fig. 2). The analysis also shows high similarity between unfolded and recently expanded leaves. The endophytes community colonizing mature leaves displayed the greatest differentiation (Fig. 2).

Endophyte abundance was only affected by leaf age ( $p$ $<0.001)$. Unfolded leaves supported lower abundance of endophytes compared to recently expanded ( $p=0.002)$, and mature leaves $(p<0.001)$, though abundance in mature and recently expanded leaves did not differ statistically $(p$ $=0.373$ ). Otherwise, the abundance of endophytes was not influenced by leaf regions of the same leaf age $(p>0.05)$. The richness of endophytes did not differ statistically among leaf age or leaf region ( $\mathrm{p}>0.05)$.

\section{Discussion}

Endophytes were abundant and diverse in the leaves of B. brevipes. The community of endophytes fit a lognormal model of taxon distribution, with few abundant taxa and several rare ones. The lognormal distribution may represent a general pattern for tropical fungal assemblages (Gamboa \& Bayman 2001). However, it should be pointed out that the community was under-sampled. The bootstrap analysis 


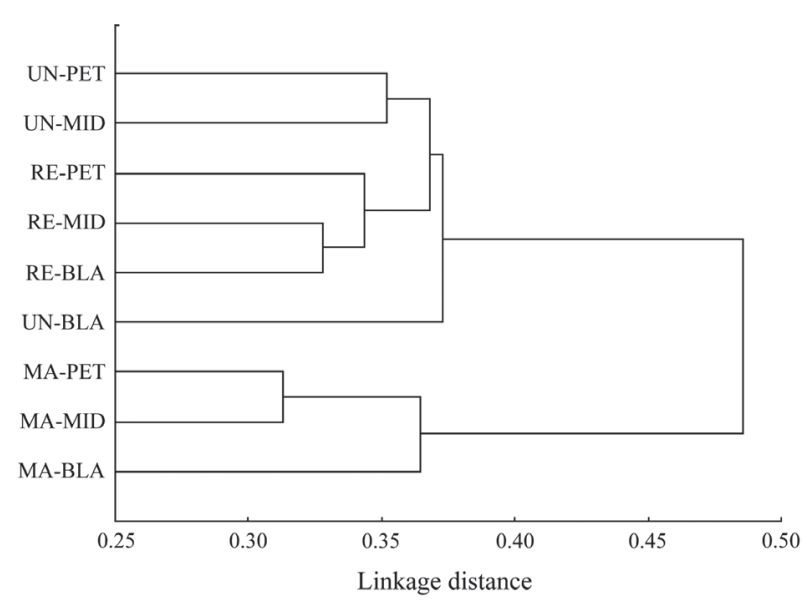

Figure 2. Dendrogram showing the relationship among the communities of endophytic fungi in the petiole (PET), mid-vein (MID) and leaf blade (BLA) of unfolded (UN), recently expanded (RE) and mature (MA) leaves of Bauhinia brevipes based on the Jaccard Similarity Index. Cophenetic correlation $=0.88$.

indicates that, although most of the expected taxa were recovered by sampling $15 \mathrm{~B}$. brevipes individuals, some taxa were not sampled. Therefore, the lack of an asymptote indicates that saturation in the taxon accumulation curve was not achieved. That fact was also observed in other surveys, and normally is explained by the hyper diversity reported in tropical endophytic fungi (Arnold et al. 2000; Arnold et al. 2001; Arnold 2005; Gamboa \& Bayman 2001).

The majority of $B$. brevipes leaves sampled in this study were colonized by endophytes. Our data corroborate the findings of Arnold et al. (2000) that suggested that the proportion of leaves colonized in tropical hosts might exceed those of temperate hosts. This prediction was supported in a recent study by Arnold \& Lutzoni (2007) who demonstrated that the percentage of colonized tissue decreases with increasing latitude.

The community of $B$. brevipes endophytes is diverse when compared to temperate species and even to some tropical plants. The richness of endophytes in B. brevipes is remarkably greater than those found in grasses (SanchezMarquéz et al. 2007) and other tropical species (Rodrigues 1994; Gamboa \&Bayman 2001; Toofanee \& Dulymamode 2002; Suryanarayanan \& Thennarasan 2004). Indeed, our estimate of endophyte richness is comparable with the assemblages recovered from the most endophyte speciesrich tropical trees (Fröhlich et al. 2000; Arnold et al. 2001) but lower than that reported for Theobroma cacao (Arnold et al. 2003).

The richness of endophytic fungi in B. brevipes is also high or similar when compared to phylogenetic related species. Other Fabaceae species harbor lower richness of endophytes (Pereira et al. 1993; Cannon \& Simmons 2002) when compared to $B$. brevipes, suggesting that phylogeny alone may not explain the high richness of leaf endophytes in B. brevipes. The reason for such richness is unknown and further studies about the ecology and the biodiversity of endophytes in the tropics are necessary to clarify our findings. As B. brevipes is a widespread species occurring in the Cerrado and in the seasonally dry tropical forests of Brazil (Caatinga) and Argentina (Chaco) (Vaz \& Tozzi 2003), the role of habitat in mediating endophyte species colonization and richness should be addressed in the future.

Nearly $25 \%$ of the B. brevipes endophyte taxa were isolated on three or less occasions. The community of endophytic fungi in tropical hosts typically comprises many species represented by only a single isolate (Arnold et al. 2000; Arnold \& Lutzoni 2007). In B. brevipes, the genus Phomopsis was the most abundant with 12 taxa. This is a common genus recovered mainly from tropical plants as an endophyte (Rodrigues 1994; Mariano et al. 1997; Taylor et al. 1999; Gamboa \& Bayman 2001; Cannon \& Simmons 2002; Silva et al. 2006; Arnold \& Lutzoni 2007) or as a pathogen (Moricca 2002). Phomopsis sp. 1 was the unique taxon found for all leaf ages, all leaf regions and in almost every individual sampled, suggesting that this fungus is widespread in $B$. brevipes leaves in the studied area. Its dominance may be related to its higher potential to colonize B. brevipes leaves, which favor its establishment and growth (Duong et al. 2006) or to negative effects on other fungi (Herre et al. 2007).

Several studies have shown that old leaves support more endophytes than relatively younger leaves (Toofanee \& Dulymamode 2002; Suryanarayanan \& Thennarasan 2004). The higher abundance of endophytic fungi in mature leaves of $B$. brevipes suggests three non-mutually exclusive hypotheses. Firstly, mature leaves are more favorable for fungal colonization. Changes in leaf biochemistry influence endophytic colonization with consequences for endophyte distribution (Fernandes et al. 2011). Moreover, young leaves are chemically more protected from herbivore attack than mature leaves (Coley 1988). Cornelissen \& Fernandes (2001) reported that as the leaves of B. brevipes aged, tannin concentration increased and herbivore attack decreased. Therefore, the increase in density of endophytes with leaf age suggests that tannins may not have the expected toxic effects on the fungus community, as previously argued by Taper \& Case (1987). Alternatively, endophyte presence could in turn increase tannin concentration. A lack of a negative correlation between endophyte abundance and leaf age should corroborate the findings of Faeth \& Hammon (1996) and Arnold \& Herre (2003) who have argued that leaf chemistry plays a minor role in endophyte colonization.

Secondly, leaf exposure time may also have accounted for increased density of endophytic fungi (Fröhlich et al. 2000; Toofanee \& Dulymamode 2002; Arnold \& Herre 2003). Arnold et al. (2003) verified that fungal endophytes associated with leaves of Theobroma cacao were horizontally transmitted and accumulated over leaf lifetimes. Moreover, the frequency of endophytes transmitted horizontally is also high in tropical regions (Arnold \& Herre 2003; Arnold et al. 2003; Arnold 2005). It is likely that the widespread occurrence of Phomopsis, Dothiorella sp., Pestalotiopsis sp. 1 and 
Pestalotiopsis sp. 2, in all leaf stages and the low similarity among the leaf ages may be related to the exposure time and horizontal transmission, rather than absolute leaf age or chemistry. Finally, mature leaves may have supported higher endophytic abundance probably due to their higher biomass providing more sites and resources for colonization when compared to young leaves (Toofanee \& Dulymamode 2002). Detailed future field and experimental studies are called for to test these hypotheses.

The composition of endophytic fungi strongly differed among leaf ages while the number of colonies was higher in mature leaves. This result not only highlights a wide diversity of endophytic fungi that can coexist in the same leaf depending on the phase of its development, but also demonstrates a temporal variation in species replacement in leaves. Toofanee \& Dulymamode (2002) suggested that the intrinsic environment of the leaves undergoes constant changes as they mature and thus the leaves support different endophytes. Endophytic fungi have been shown to be tissue-recurrent in several studies (Cannon \& Simmons 2002; Duong et al. 2006), but the mechanisms underlying tissue-recurrence are not entirely understood (Hyde \& Soytong 2007). Our data show that although leaf region appears not to have affected the abundance and richness of endophytic fungi, it caused changes in the composition of the endophytic community. It remains to be investigated whether spatial niche differentiation would result in competition avoidance and consequent endophyte coexistence within leaves.

\section{Acknowledgments}

We thank L.T.D. Vieira and L. Pfenning for identifying the endophytic fungi, E. Christie and C. Sá for field assistance and S.H. Faeth and G.C. Carroll for sending important references. We are especially grateful to $\mathrm{T}$. Cornelissen for comments on the manuscript and K. Hyde for his contribution. This research was supported by $\mathrm{CNPq}$ (Proc. 472491/2003-2, 304851/2004-3, 476178/20088, 303352/2010-8, 474292/2010-0, 559279/2008-6, 558250/2009-2, 151817/2008-1), FAPEMIG (Proc. APQ 01278-08, EDT 465/07, RDP-00048-10) and CAPES (Proc. BEX 323710-9, Proc. 02/2009 DRI/CGCI). We also thank the Estação Ecológica de Pirapitinga-IBAMA for logistical support.

\section{References}

Arnold, A.E. 2005. Diversity and ecology of fungal endophytes in tropical forests, Pp. 49-68. In: Deshmukh, S. (Ed.). Current Trends in Mycological Research. New Delhi, Oxford \& IBH Publishing Co. Pvt. Ltd.

Arnold, A.E.; Henk, D.A.; Eells, R.L.; Lutzoni, F. \& Vilgalys, R. 2007. Diversity and phylogenetic affinities of foliar fungal endophytes in loblolly pine inferred by culturing and environmental PCR. Mycologia 99: 185-206.

Arnold, A.E. \& Herre A. E. 2003. Canopy cover and leaf age affect colonization by tropical fungal endophytes: Ecological pattern and process in Theobroma cacao (Malvaceae). Mycologia 95: 388-398.

Arnold, A.E. \& Lutzoni, F. 2007. Diversity and host range of foliar fungal endophytes: are tropical leaves biodiversity hostpots? Ecology 88: 541-549.

Arnold, A.E.; Maynard, Z. \& Gilbert, G.S. 2001. Fungal endophytes in dicotyledonous neotropical trees: patterns of abundance and diversity. Mycological Research 105: 1502-1507.

Arnold, A.E.; Maynard, Z.; Gilbert, G.S.; Coley, P.D. \& Kursar, T.A. 2000. Are tropical fungal endophytes hyperdiverse? Ecology Letters 3: 267-274.

Arnold, A.E.; Mejia, L.C.; Kyllo, D.; Rojas, E.I.; Maynard, Z.; Robbins, N. \& Herre, E.A. 2003. Fungal endophytes limit pathogen damage in a tropical tree. PNAS 100: 15649-15654.

Barnett, H.L. \& Hunter, B.B. 1972. Illustrated genera of imperfect fungi. 3 ed. Minnesota, Burgess Publishing Companhy.

Cannon, P.F. \& Simmons, C.M. 2002. Diversity and host preference of leaf endophytic fungi in the Iwokrama Forest Reserve, Guyana. Mycologia 94: $210-220$.

Carroll, G.C. 1988. Fungal endophytes in stems and leaves from latent pathogen to mutualistic symbiont. Ecology 69: 2-9.

Cheplick, G.P. \& Faeth, S.H. 2009. Endophytes and host-plant herbivore relationships. Ecology and Evolution of the Grass-Endophyte Symbiosis 26: 50-75.

Coley, P.D. 1988. Effects of plant growth rate and leaf lifetime on the amount and type of anti-herbivore defense. Oecologia 74: 531-536.

Colwell, R.K. 2006. EstimateS: statistical estimation of species richness and shared species from samples. http://viceroy.eeb.uconn.edu/ EstimateS.

Conover, W.J. 1980. Practical nonparametric statistics. New York, John Wiley \& Sons.

Cornelissen, T.G. \& Fernandes, G.W. 2001. Patterns of attack of two herbivore guilds in the tropical shrub Bauhinia brevipes (Leguminosae): vigor or chance? European Journal of Entomology 98: $37-40$.

Cornelissen, T.G.; Madeira, B.G.; Allain, L.R.; Lara, A.C.F.; Araújo, L.M. \& Fernandes, G.W. 1997. Multiple responses of insect herbivores to plant vigor. Ciência e Cultura 49: 285-288.

De Hoog, G.S.; Gottlich, E.; Platas, G.; Genilloud, O.; Leotta, G. \& Brummelen, J. 2005. Evolution, taxonomy and ecology of the genus Thelebolus in Antartica. Studies in Mycology 51: 33-76.

Devarajan, P.T. \& Suryanarayanan, T.S. 2006. Evidence for the role of phytophagous insects in dispersal of non-grass fungal endophytes. Fungal Diversity 23: 111-119.

Duong, L.M.; Jeewon, R.; Lumyong, S. \& Hyde, K.D. 2006. DGGE coupled with ribosomal DNA gene phylogenies reveal uncharacterized fungal phylotypes. Fungal Diversity 23: 121-138.

Faeth, S.H. \& Hammon, K.E. 1996. Fungal endophytes and phytochemistry of oak foliage: determinants of oviposition preference of leafminers? Oecologia 108: 728-736.

Fernandes, G.W. 1998. Hypersensitivity as a phenotypic basis of plant resistance against herbivory. Environmental Entomology 27: 260-067.

Fernandes, G.W.; Oki, Y.; Sanchez-Azofeifa, A.; Faccion, G. \& AmaroArruda, H.C. 2011. Hail impact on leaves and endophytes of the endemic threatened Coccoloba cereifera (Polygonaceae). Plant Ecology DOI: 10.1007/s11258-011-9941-z

Fröhlich, J.; Hyde, K.D. \& Petrini, O. 2000. Endophytic fungi associated with palms. Mycological Research 104: 1202-1212.

Gamboa, M.A. \& Bayman, P. 2001. Communities of endophytic fungi in leaves of a tropical timber tree (Guarea guidonia: Meliaceae). Biotropica 33: 352-360.

Gonçalves-Alvim, S.J. \& Fernandes, G.W. 2001. Biodiversity of galling insects: historical, community and habitat effects in four neotropical savannas. Biodiversity and Conservation 10: 79-98.

Herre, E.A.; Mejia, L.C.; Kyllo, D.A.; Rojas, E.; Maynard, Z.; Butler, A. \& Van Bael, S.A. 2007. Ecological implication of anti-pathogen effects of tropical fungal endophytes and mycorrhizae. Ecology 88: $550-558$.

Hyde, K.D. \& Soytong, K. 2007. Understanding microfungal diversity - a critique. Cryptogamie Mycologie 28: 281-289. 
Magurran, A.E. 1988. Ecological diversity and its measurement. Princeton, Princeton University Press.

Mariano, R.L.R; Lira, R.V.I; Silveira, E.B. \& Menezes, M. 1997. Levantamento de fungos endofíticos e epifíticos em folhas de coqueiro no nordeste do Brasil. I. Freqüência da população fúngica e efeito da hospedeira. Agrotrópica 9(3): 127-134.

Mejía, L.C.; Rojas, E.I.; Maynard, Z.; Van Bael, S.; Arnold, E.; Hebbar, P.; Samuels, G.J.; Robbins, N.\& Herre, E.A. 2008. Endophytic fungi as biocontrol agents of Theobroma cacao pathogens. Biological Control 46: 4-14.

Moricca, S. 2002. Phomopsis alnea, the cause of dieback of black alder in Italy. Plant Pathology 51: 755-764.

Murali, T.S.; Suryanarayanan, T.S. \& Venkatesan, G. 2007.Fungal endophyte communities in two tropical forests of southern India: diversity and host affiliation. Mycological Progress 6:191-199.

Myers, N.; Mittermeier, R.A.; Mittermeier, C.G.; Fonseca, G.A.B. \& Kent, J. 2000. Biodiversity hotspots for conservation priorities. Nature 403: 853-858.

Pereira, J.O.; Azevedo, J.L. \& Petrini, O. 1993. Endophytic fungi of Stylosanthes: a first report. Mycologia 85: 362-364.

Riddell, R.W. 1950. Permanent stained mycological preparations obtained by slide culture. Mycologia 42: 265-270.

Rodrigues, K.F. 1994. The foliar fungal endophytes of the Amazonian palm Euterpe oleracea. Mycologia 86: 376-385.

Rodriguez, R.J.; Redman, R.S. \& Henson, J.M. 2004. The role of fungal symbioses in the adaptation of plants to high stress environments. Mitigation and Adaptation Strategies for Global Change 9: 261-272.

Sanchez-Márquez, S.; Bills, G.F. \& Zabalgogeazcoa, I. 2007. The endophytic mycobiota of the grass Dactylis glomerata. Fungal Diversity 27: 171-195.

Santos, J.C.; Silveira, F.A.O. \& Fernandes, G.W. 2008. Long term oviposition preference and larval performance of Schizomyia macrocapillata (Diptera: Cecidomyiidae) on larger shoots of its host plant Bauhinia brevipes (Fabaceae). Evolutionary Ecology 22: 123-137.
Silva, R.L.O.; Luz, J.S.; Silveira, E.B. \& Cavalcante, U.M.T. 2006. Fungos endofíticos em Annona spp.: isolamento, caracterização enzimática e promoção do crescimento em mudas de pinha (Annona squamosa L.). Acta Botanica Brasilica 20: 649-655.

Suryanarayanan, T.S. \& Thennarasan, S. 2004. Temporal variation in endophyte assemblages of Plumeria rubra leaves. Fungal Diversity 15: 197-204.

Taper, M.L. \& Case, T.J. 1987. Interactions between oak tannins, and parasite community structure: unexpected benefits of tannins to cynipid gall-wasps. Oecologia 71: 254-261.

Taylor, J.E.; Hyde, K.D. \& Jones, E.B.G. 1999. Endophytic fungi associated with the temperature palm, Trachycarpus fortunei, within and outside its natural geographic range. New Phytologist 142: 335-346.

Tejesvi, M.V.; Kini, K.R.; Prakash, H.S.; Subbiah, V. \& Shetty, H.S. 2007. Genetic diversity and antifungal activity of species of Pestalotiopsis isolated as endophytes from medicinal plants. Fungal Diversity 24: 37-54.

Toofanee, S.B. \& Dulymamode, R. 2002. Fungal endophytes associated with Cordemoya integrifolia. Fungal Diversity 11: 169-175.

Vaz, A.M.S.F. \& Tozzi, A.M.G.A. 2003. Bauhinia ser. Cansenia (Leguminosae: Caesalpinioideae) no Brasil. Rodriguésia 54: 55-143.

White, T.J.; Bruns, T.; Lee, S. \& Taylor, J. 1990. Amplification and direct sequencing of fungal ribosomal RNA genes for phylogenetics, Pp. 315-322. In: Innis, M.A.; Gelfand, D.H.; Sninsky, J.J. \& White, T.J. (Eds.) PCR Protocols: A guide to methods and applications. San Diego: Academic Press.

Wilson, D. 1996. Manipulation of infection levels of horizontally transmitted fungal endophytes in the field. Mycological Research 100: $827-830$.

Zar, J.H. 1996. Biostatistical analysis. third ed. Prentice Hall, New Jersey. Zaurov, D. E.; Bonos, S.; Murphy, J. A.; Richardson, M. \& Belanger, F. C. 2001. Endophyte infection can contribute to aluminum tolerance in fine fescues. Crop Science 41: 1981-1984. 